\title{
A REVIEW OF THREATENED AND RISKED ENTOMOPHAUNA ON SHKODRA LAKE AREA
}

\author{
Ariana Striniqi Laçej*, Kastriot Misja \\ "Faculty of Natural Sciences, University of Shkodra "Luigj Gurakuqi", Albania; University of Tirana, Albania; \\ *Corresponding author Ariana Sterniqi Laçej, e-mail: a.striniqi@ yahoo.com;
}

Received February 2019; Accepted March 2019; Published April 2019;

DOI: https://doi.org/10.31407/ijees9205

UOI license: http://u-o-i.org/1.01/ijees/28382963

\begin{abstract}
In this paper are presented some Shkodra Lake Area Entomophauna species that are endangered in this habitat and have their threatened categories at the national level based on the Red List of IUCN (International Union for the Protection of Nature). There are exactly 39 species with their risked categories. These data are derivative of a several-year monitoring, based on expeditions carried out in different areas in this aea. About 39 species of Insects Order (Odonata 2 species, Mantopera 2 species, Neuroptera 2 species, Lepidoptera 24 species, Coleoptera 9 species) from different regions of Northern Albania. Most of them seem to be threatened on their habitats, belonging to the IUCN red list, where: 30 species belong to the vulnerable category (VU), such as Erynnis Tages; 6 are near threatened species (LR), such as Lestes Dryas; 2 are endangered (EN), such as Gmnopleurus Mopsus; 1 are critically endangered (CR) such as Osmoderma Eremita. Some of threatening aspects we can point out are related with this habitat, like the deterioration or disturbing, especially during reproductive period (i.e. before the egg disposal), pollution of waters and other ecological changes. The quality of water is considered good. [1,2]. We wish to contribute in the further knowledge of Insectophauna of Albania Region, focusing also in preservation and conservation of endangered species and their respective habitats, especially warm field-hilly regions, warm lower grass areas, rich vegetation areas and water heated areas. Most of them have a negative impact on ecological system [3].
\end{abstract}

Key words: threatened species, endangered species, IUCN category, Red List of Insects, habitat, scientific name, chorology, bio-ecology of species. 